\title{
設備機械用刷子仕樣書の解說と
}

\section{6 年度刷子試驗計畫について}

\author{
國鐵技術硛究所赤 沼 哲 郎
}

\section{1. 緒言}

昭和 24 年つ初的當時の本省電匊局の依賴で, 設備機械刷子規格並に瞒入仕樣書を立案した。 主 として英國 Morganite 社, 獨息 Ringsdarff 社 米國 National. 社、等飞て集为られ壳仕椂書なら

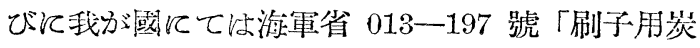
素規格」昭和 9 年 3 月制定，電氣拹會關束支部 「電莱車主電動機朋刷子規格」昭和 16 年 8 月決 定, 鐵道省車輛局「刷子購入仕樣書」等を參考之 し, 更らそ特性の数值につんては, 學術振興會第 117 委員會の各委員が調侐發表されたものおよび 國鐵技術研咒所實驗資料等を參考己して試案をね り, 數泡の委員會飞懸け, 昭和 24 年 10 月に決 定を兒をるのである。

內容恃甲種, 電 78501 號, 乙種, 78502 號, 丙 種 78503 號の 3 部門, すな⿰力口種は整流用刷子 乙種は集電噮朋刷子，丙種は刷子試驗法の三部に 分類され詳細に規程されている.

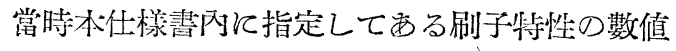

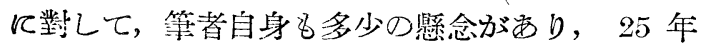
1月より 3 月迄に實地試驗飞低つてその信賴性に つんて確められた。すなお方 25 年度の蕒地試驗 は實驗のをめの試驗で西つて，てれによつて仕椂 書內の数字山適當な值でする事を確的得をので西 る. 從つて 26 年度においては 25 年度の試驗成 積之刷子の特性之を十分に洘慮に入れを確信の西 る試驗を蛽施し得る己思れる. 以下各仕樣㫪に指 定されて远る數值打よびその要點, 並に特異點に つき述へ，加えて 26 年度の試驗計畫につんて記 述しよう.

\section{2. 甲種および乙種仕樣について}

「發變電および車電用ブラシ甲種 (乙種) 仕樣
畫」は雨者共に同一形式にて同一條項分洞一要項 に振れている. 從つて兩者の獨得なる點の夕は異 るが，他㹥全く同一乙見て良い，全文 5 章 16 條 よりなつてんて, 立案に際しては委秋の事柄に つんて十分教虑を拂い立案しを. すなわち

a 優秀な材質を製造する良心的度紫者牥成す べきてと.

b 惡質度業者並にプローカーの介在するる餘地な からしわること，但し正規なプローカーは認 めること.

c 材質の特性に關する數值は出來るだけ嚴格己 し，材質の改良己共に仕樣書の值逐次進步 せしめ得るこ之。

d 各業者飞指定の試驗設備を有せしめ, 品質の 改良を計る己共に納品に對しての責任を覓わ しめるここ.

$\mathrm{e}$ 納入檢査, 中間檢查等にては出來得る限り菜 者の負据を輕くし，且つ監督員にもその憸查 の繁雜を少くするここ.

等につんて洘虑した.

\section{甲種および乙種仕杨書の特異點}

甲種および乙種仕樣書の特筫點につんてその解 說を述れば大體次の如き諸項さなる.(甲種乙種同 時に解說し，異る點のみを別に指ず)

\section{A 笨 1 章 一般事項}

$a$ 認定せられるべき刷子の特性:は本仕樣書に指 示してある數值に合格しなければならぬ事は勿論 であるが，同時に公式實地試驗に合格しそ成續表 を必㛐とする事となつている。すなわ占特性の試

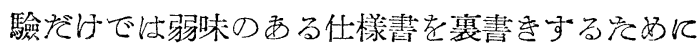

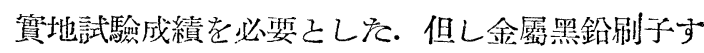
なわち乙種仕樣書には 100 倍で撮影しそ㙷徵鏡寫 真を添付する事となつている. (第 3 低)

b 惡質な刷子プローカーによる系統不明な材質 
の納入を防ぐをめに，如何なる場合でも製造者名 材質名，製造年月等を明記しを書類を必要さずる

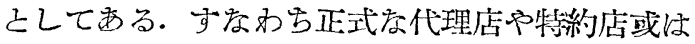
加工專門事菜者を認め，惡質プローカ一を締出し するのが本條の目的である. (第 4 條)

B 第2章 材筫沶よび工作

a 原料，特飞黑鉛及銅粉並飞黑鉛化原料を吟味 するをるに第 7 條を設けてある. 即ち黑鉛化原料 を用ん，一次低溫燒成だけで黑鉛化刷子乞稱して 納入するが如きで，斯る不正を防止する目的で甲 種には「製造最終工程に事んて黑鉛化せるるの」 己离り又乙種には「純粹友る電氣銅上り製造出る。 銅粉並に純粹走る黑鉛より学当言々」之表示して 西る.(第 7 條)

b一般の仕樣書に於へては實際寸法の公差を公 稱寸法より幾分緩和岕しわるのが普通で西るが, 本仕㩐書にては雨者を同樈に取扱ん.日本標準規 格の値をとのま小使用ずる事己しを. (第 8 悠第 1 項)

c 同條第 2 項で岋䞯線を規定して西る. 戰前使 用されていたものは主こして素線の太さを 0.08 mm 以下でめつたが戰時規格として $0.1 \sim 0.12$ $\mathrm{mm}$ の素線学使用されるに至つ\%。，今回忙甲種に ては $0.1 \mathrm{~mm}$ 以下, 乙種にては $0.12 \mathrm{~mm}$ 以下 の素線学使用する事とし，更らにその容量につん ては，有效面積を指定せすにとの代り溫度上暑に て抑えて車る，從つて銅線の質及太さ等の网方子

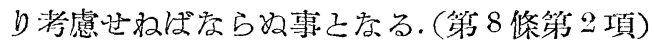

d 導線の取付方法にも別に指定を設けてない。

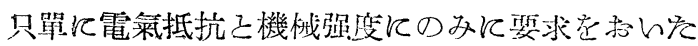
機械的强度を指定し党つは今回が初的ての武みで 要尚. (第 8 條第 3 項)

e 端子纪，特飞銅線己金具己を牛田付于する 事を指定し，從來此の部所上り起る障害を少亦ら し的上うこし它. (第 8 堡第 3 項)

$\mathrm{f}$ 次飞金具飞使用される金屬板の厚さに制限を 與えを。節ち銅入は鐵の $1.6 \mathrm{~mm}$ ，以上のるのを

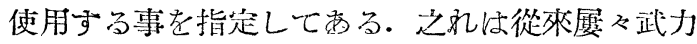

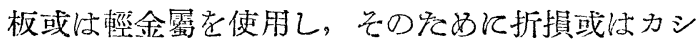
メ部分に凹曲学變形を來す場合が少くなかつを。

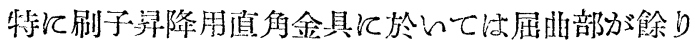

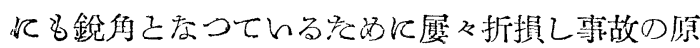

困己なる皆合が多かつ民事に鑑み，屈旺部內側の 曲率牛徑を使用せる板の厚さ之同じで事るべき事

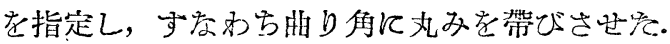
(第 8 條第 5 項)

$\mathrm{g}$ 標示の方法從來業者及名柄のマークを゙けで 西つをものを，今回は更らに製造年月をも印儿， 事故發生の易合飞於汀る責任を明ら加に，又業者 側に於ける調查にも便利ならしめるようにして。

(第 8 條第 8 項)

\section{C 第3 章 試 驗}

a 本仕樣書飞低る試驗飞は試驗要項及試驗機を 指定して两るが，しかし指定以外つ試驗機器を使

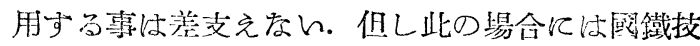

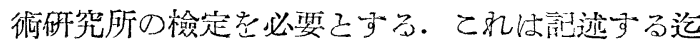
もなく炭素材料は，その特徵己して，試驗機器 及試驗方法が異れば，その測定值に可成り大き存 差異を表す事が屡心为るので，此の障害を防ぐ目 的之, 更らに餘り高價で学 試驗器機は出來るだ け，統一して各莱者に設備させ，技術の向上を計

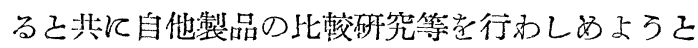
しての目的も含れでる. 但し餘りに高價な試驗 設備，或は特に技衡を姴する試驗法等につんては 深くふれ秃その大要だけを押えて叻る。本仕樣 書にて恐求されている特性の範園忹第 1 表及第 2

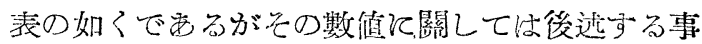
己学京. (第 9 條)

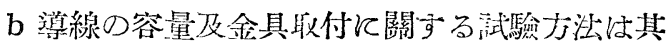
の規定電流を流し汽場合の溫度上暑沉て押え，其

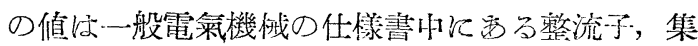
電環の溫度上昇の數值を以つて表示乙を。(第10條 第 1 項)

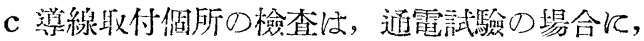
同時飞該部分の電壓降下を测定し，その抵抗值が 0.005 オーム以下でなければをらぬ己規定してあ る. 從來の仕様書にては 0.001 を限度として品る が，多くの統計の絬果より現在使用中のものは, $0.002 \sim 0.003$ オーム程度のものが最子多く, 月 転故の直接原困己して現れる場合は 0.008 オ一 ム以上の值を有しているものが多い等, 又乙種す

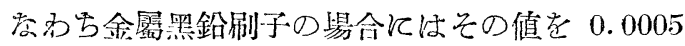

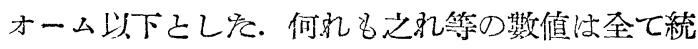

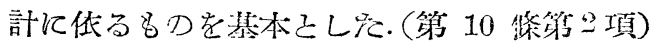




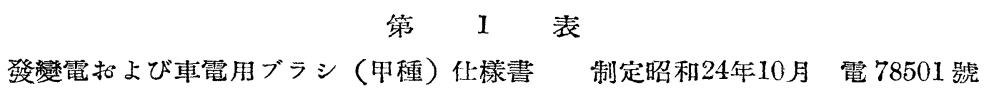

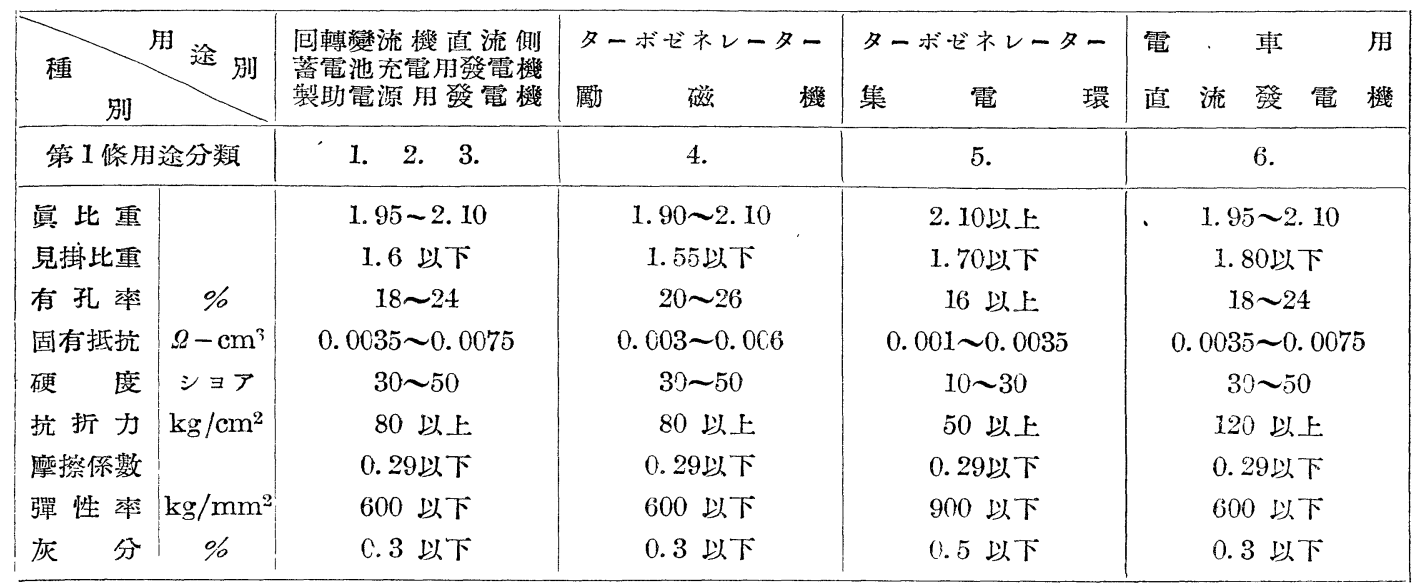

第 2 表

發變電扎よび車電朋ブラシ（乙種）仩樣書＼cjkstart制定昭和 24 年10月 電 78502 號

\begin{tabular}{|c|c|c|c|c|}
\hline \multicolumn{2}{|c|}{ 種 别 途 別 } & 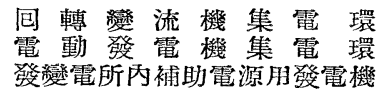 & 水車發電機集電環 & $\begin{array}{l}\text { 䖝光燈 用 發電 } \\
\text { 動 㗀 直 流 側 }\end{array}$ \\
\hline \multicolumn{2}{|c|}{ 第 1 條用途分類 } & 1. 2. & 4. & 5. \\
\hline 見 掛 比重 & & 5.5 以下 & 5.5 以下 & 5.5 以下 \\
\hline 固 有 抵 & $\Omega-\mathrm{cm}^{3}$ & 0.001 以下 & 0.0004 以下 & 0.0001 以下 \\
\hline 硬 & $シ ョ ア$ & $8 \sim 23$ & $10 \sim 20$ & $8 \sim 18$ \\
\hline 折 & $\mathrm{kg} / \mathrm{cm}^{2}$ & 200 以上 & 200 以上 & 200 以上 \\
\hline 擦 係 & & 0.27 以下 & 0.27 以下 & 0.27 以下 \\
\hline 彈性率 & $\mathrm{kg} / \mathrm{mm}^{2}$ & 4500 以下 & 3500 以下 & 3000 以下 \\
\hline 黶面膨脹率 $\left(300^{\circ} \mathrm{C}\right)$ & $\%$ & 0.6 以下 & 0.6 以下 & 0.6 以下 \\
\hline 側面膨脹率 （" ） & $\%$ & 0.5 以下 & 0.5 以下 & 0.5 以下 \\
\hline 膨 脹 差 ("I') & $\%$ & 0.2 以下 & 0.2 以下 & 0.2 以下 \\
\hline (常溫) & $\%$ & 0.2 以下 & 0.2 以下 & 0.2 以下 \\
\hline
\end{tabular}

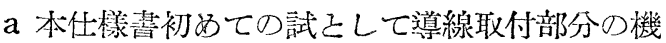
械的强度飞制限を與えて西る。す质わち製品之な つそ刷子のま小で引張試驗を行う。例え壮 4 本り

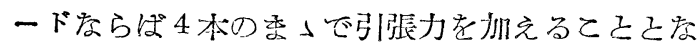
る. しかしてその强さを $10 \mathrm{~kg}$ 以上乙制限しそ. 一般市販刷子にて，接觸面が $1 \mathrm{~cm}^{2}$ 以上のもの 35 ケにつき韭驗しを結果に依れば普通 $30 \mathrm{~kg}$ 程度 で西り，最高42 kg 最低 $18 \mathrm{~kg}$ で西つ尼。粗惡 品を加えれば本均牥 $13 \mathrm{~kg}$ 程度已なる故飞 $10 \mathrm{~kg}$

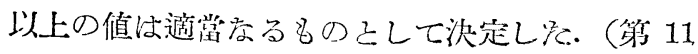
條)

D) 第 4 章 檢 查

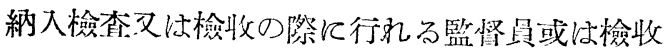

員の檢榃方法を出來るだけ簡易に行い得るように し，相互の便利を教虑して次の如く沈是しを。

a 檢查法は現在行われている拔取檢查法には幾

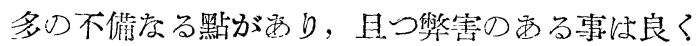

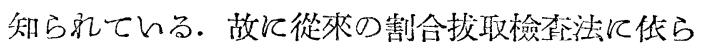

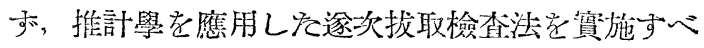

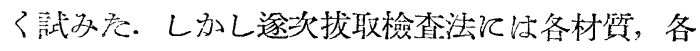

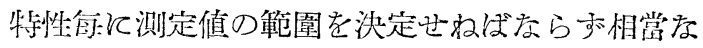
準備調查孝必要己するので，急速には間に合和上 むを得和從來の方法に低る事己し完. 此の祭に檢

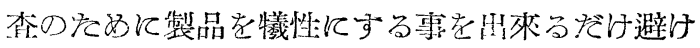
拔取數を全數の $4 \%$ 亿減し加えて固们抵抗及硬

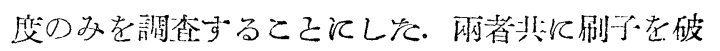


56

若

壞するてこなしで行い得るからである。而して測 定平均值の許容範圍は前者を $\pm 25 \%$ とし後者

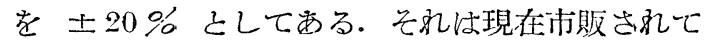
らる優良刷子の本均值の承り方を推計學上り求め て決定しを值で西る.(第 12 條)

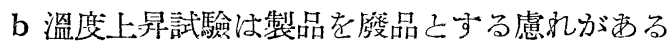
ので全數の $2 \%$ とし同時に緮線の接觸抵抗をも 测定する事己しを. (算 13 條)

c 引脹試驗飞よる接續ヶ所の機㭜的溫度は製品 を破壞せしめなければ試驗し得ない程類のもので 西る故に, 更らにその數を減し全敖より 2 3 個 だ仔拔取り試驗を實施して成續を出す事とした。

(第 13 條)

d 以上の如く立會檢查，或恃納入檢查を笛來る だけ簡略化した理由は, 菜者を笔態調査, 或は設 備調查等に低り十分その信用の度合を調查しを上 は當局側乙しても策者を十分飞信用して良しい己 言う專で西り，又信用出來る業者で西るならば繁 雜な各種試驗を行う必要も字く, 一方嚴重な試驗 を行つてる餘り深々意味をもた交いと言う見解か らである。しかし業者に對ずる信用つ如何に低つ ては全項に亘る試驗を實施する必要が西るので,

「昜合に應じては各種の試驗を行うここも西る」 この條交を㧈えてある. (第14條)
素

$\mathrm{E}$ 第 5 章 荷 造り 特異點はない

\section{3. ブラシ試驗要項について}

試驗要項は甲乙丙種の仕樣書に適し得るように 共通存形で定案された。而して將來は國鐵炭素材 料關係全部の共通試驗法に育て」見とんと考えて 々る.

a 各種試驗に使用さ礼る試驗片の寸法を統一し これて種別每の名稱を與え，仕上げ寸法に對する 許容誤差を制限した。 その種類及寸法は第 3 表の 如くである.(第 3 條)

第 3 表

\begin{tabular}{|c|c|c|c|}
\hline 種別 & 厚さメ幅 $\times$ 長さ & 本數 & 試驗の種別 \\
\hline $\mathrm{A}$ 種 & $10 \times 10 \times 60$ & 10 & $\begin{array}{l}\text { 抗折才, 抵抗, 硬度 } \\
\text { 見掛比重 }\end{array}$ \\
\hline B種 & $10 \times 20 \times 40$ & 10 & 衝摮, 摩耗, 整流 \\
\hline $\mathrm{C}$ 種 & $3 \times 6 \times 60$ & 2 & 彈性係數 \\
\hline $\mathrm{D}$ 種 & $2 \times 4 \times 60$ & 2 & 粘性係數 \\
\hline $\mathrm{E}$ 種 & $4 \times 8 \times 14$ & 2 & 摩擦係數 \\
\hline $\mathrm{F}$ 種 & $3 \times 3 \times 60$ & 2 & 㴊性率 \\
\hline G 種 & $10 \times 10 \times 40$ & 2 & 膨脹率 \\
\hline
\end{tabular}

（第3 表に於いて，D種㤌仕樣青本文中に未決定 F 種は本文に文仕樣書にも記載されていない。

第 4 表

\begin{tabular}{|c|c|c|c|c|c|c|c|c|c|}
\hline 湎 & 試驗項目 & $\begin{array}{l}\text { 测 } \\
\text { 定 } \\
\text { 测 } \\
\text { 定 法 } \\
\text { 機 }\end{array}$ & 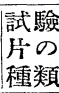 & $\begin{array}{l}\text { 試驗片寸 } \\
\text { 法の許容 } \\
\text { 哭差 }\end{array}$ & $\mid \begin{array}{l}\text { 一試 } \\
\text { Kつ } \\
\text { 倒定菖 }\end{array}$ & $\begin{array}{l}\text { 試驗 } \\
\text { 值の } \\
b_{2}\end{array}$ & $\begin{array}{l}\text { 測定 } \\
\text { 點合 } \\
\text { 訫 }\end{array}$ & 測 & $\begin{array}{l}\text { 湘定傎の } \\
\text { 有效數 }\end{array}$ \\
\hline 1 & 亨比重 & ベンゾール法 & $\cdots$ & 一 & - & 一 & 3 & 學振法 & 3 枌迄 \\
\hline 2 & 見掛比重 & 寸法重量法 & A & $\begin{array}{l}\text { 小數第 } \\
1 \text { 位迄 }\end{array}$ & - & 3 & 3 & $1 / 20$ バー ニヤ付ノギス & 2 枌迄 \\
\hline 3 & 有 孔率 & 1.2 にて計算 & 一 & 一 & 一 & - & 3 & $" \prime$ & 2 栴过 \\
\hline 4 & 固有抵抗甲 & 電湭降下法 & A & - & 8 & 3 & 24 & $\begin{array}{l}100 \text { オームの內部抵抗あるミリボ } \\
\text { ルトメーター lamp 10mm 間隔 }\end{array}$ & 2 析䓕 \\
\hline 5 & 同上 乙 & $" \prime$ & $\prime \prime$ & - & 8 & 3 & 24 & $5 \mathrm{amp} 20 \mathrm{~mm}$ 間隔 & " \\
\hline 6 & 硬度 & $\equiv \quad \exists \quad \gamma$ & $" \prime$ & - & 6 & 3 & 18 & 學振と略々同樣 & $\begin{array}{l}\text { 厴側各面につ } \\
\text { き } 2 \text { 枌迄 }\end{array}$ \\
\hline 7 & 抗 折 力 & $\begin{array}{l}\text { オルセンスは } \\
\text { アームスラー }\end{array}$ & $"$ & - & 1 & 5 & 5 & 學振法と略々同摩 & (to \\
\hline 8 & 摩擦㛊數 & $\begin{array}{l}\text { 光學式 } \\
\text { バネ本衡型 }\end{array}$ & $\mathrm{E}$ & - & - & 2 & 1 & $\begin{array}{l}\text { 試驗機を指定す } \\
\text { 室溫 } 20 \sim 30^{\circ} \mathrm{C} \text { 濕度 } 50 \text { ～} 80 \%\end{array}$ & $\begin{array}{l}\text { 第 } 3 \text { 枌は參考 } \\
2 \text { 析迄 }\end{array}$ \\
\hline 9 & 彈. 性 率 & 反射 口式 & $\mathrm{C}$ & $\mid$\begin{tabular}{|c|} 
小數 第 \\
1 位以下
\end{tabular} & 3 & 2 & 6 & $\begin{array}{l}\text { 試驗機指定 } \\
\mathrm{e}=40 \quad \mathrm{~W}=200 \quad \mathrm{r}=1\end{array}$ & 2 桁迄 \\
\hline 10 & 分 & - & - & - & 一 & - & 3 & 學桭法と略々同樣 & $\begin{array}{l}2 \text { 茠迄 } \\
\text { 參考灰の色 }\end{array}$ \\
\hline 11 & 膨脹 染 & $\begin{array}{l}\text { 本多式又は } \\
\text { 鐵 研 式 }\end{array}$ & $\mathrm{G}$ & - & 2 & 2 & 2 & $\begin{array}{l}\text { 試驗機指定す } \\
300^{\circ} \mathrm{C} \text {, 㻺側面につき }\end{array}$ & $\left(\begin{array}{l}4 \text { 種データー) } \\
2 \text { 桁迄 }\end{array}\right.$ \\
\hline
\end{tabular}


本年度には第 3 表の如く改正の踭定である)

b 第 4 條第1. 項上り第 11 . 項に至る迄は各種の 試驗法につんて指定して西る。，之を理解し易く表 示すれ第 4 表の通りである。

以上の如く第1 項上り第 11. 項迄は各試驗法に つんて規程して西るが，その內摩擦係數，彈性率 及膨脹率の測定の試驗器を指定して。すをわ ち刷子使用者側乞して最子重要で西り, 且つ直 接江關係市る特性は炭素刷子では摩擦係數之彈

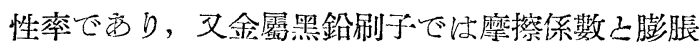
係數の各二者である。乙秃等の特性引゙指定してい る值以內にない歾合は例元他つ特性が如何に優秀

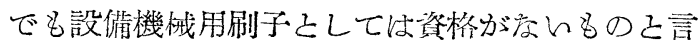
々得る. 又見掛比重. 强性率つ测定用試驗片のみ その寸法を嚴重々指定して承るのはこれ等の特性 の值牥試驗片の寸法の誤差山相當大きな影響を與

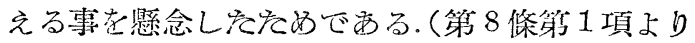
第 11 項迄)

以上に甲種乙種丙種各仕様書に表的特異度點 の大約を記述してもので西るが，詳細は本交を參 照せられたん。

\section{4. 第1表，第2表の特性值について}

a 笨1 表, 表中の用途分類の番號中 5 項の夕は 天然黑鉛質を，他は全て電菊黑鉛質を使用しても 乷支ない事を狙つている。從つて真比重の值は 2.10 以上に指定してある. Lかし灰分のみは天

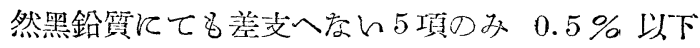
そし，他は $0.3 \%$ 以下に押えを.

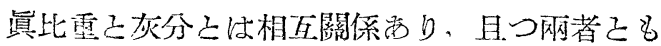
摩擦係數汇關連してんる事的一般に良く知られて んるが，しかしその理論は明らかにされていな い從つて之等の特性储に對して子現在各䅺市販刷 子小優秀なものにつき調企し結䏡よりその值の 範園を決定したので西る。

固有抵抗㹥普通 $0.004 \sim 0.005$ オームを中心飞

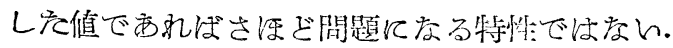

又機械的强度を表す硬度抗折力以設併機械用刷子 に隄り餘り重要視する必要証無々。故に思々切り 低々。 しか子範園を廣的值に定め灰。

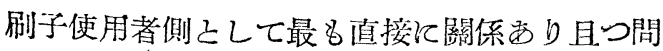
㩆之なる特性は摩擦係數已彈性率べ゙るるで此の
值は䱋重を期して決定しを. 一般に刷子取付角度 郎方追隨型 19 度反撥型の 32 度の角度の決定は 刷子の縻擦係數を 0.3 として阡算を起している ので，少なくるも此の值より少くなけ礼ばなら ぬ. 乙かして任樣書のこの值を決定償つては內 地品中の代表的店ものが $0.27 \sim 0.28$ を最大之す る值である己言ふ實驗絡果に基いて 0.29 之決定

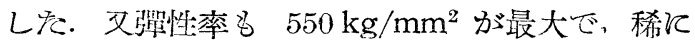
$600 \mathrm{~kg} / \mathrm{mm}^{2}$ の材質も西るとの調查の結果より, $600 \mathrm{~kg} / \mathrm{mm}^{2}$ 己決定した.

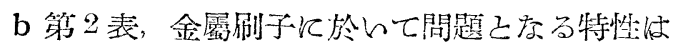

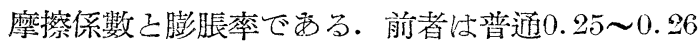
程度を有しているのが一般ざ西る。しかし後者は 其の特性の實测值を發表されたものは餘り見受け られ和筆者の賽驗しを絬果值や或は障害を起しを 溯于の膨脹を测定しだ結果等索綜合して第2表の 值老決定した。 しかして常溫に和ける膨脹を表示

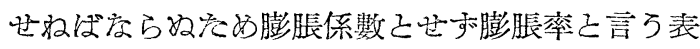
示をすること己した。

第 2 表に於ける見掛比重の值で含有銅粉の星を 制限してある事任記速する迄飞去ん.

以上代樣書內に指示した特性中最名重琶なもの につレて 2〜3 說明しをが摩擦係數の测定は指定 测定器を標準こし入力法に依る测定值を參考にし 又㖓性率の测定忛指定测定器を標準己して, 二反 射鏡式に依つて得を值艺參考とした. 但し膨脹率 のみ鐵研式にて测定し 1/1000 mm の测微顯微鏡 そてその值を確めをものである。

\section{25 年度刷子實地試驗について}

前述の如くして制定を見を設備用刷子の仕樣書 內に決定されている特性の數值は實際に刷子を使 用しを場合に果して適合するや否を檢しなければ 次らい。この孝めに昭和 25 年1月より 3 月 迄國鐵三島變亚に新鶴見變にて䔈地試驗を試みら れを。供試されて刷子中規格を僅か外れをるの,

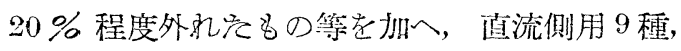
交流側用 12 檑にて, 雨變共に同型式の芝浦, 日立製の機械にて行つそ. 但し此の昜合規桥外 の特性を有している事は公開せず，且つ實地試 驗の成績につんて的特性調查を行つを筆者等つ意

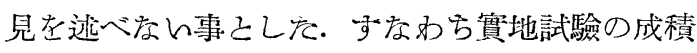
壮現場區長の責任とし又特性試驗成績は筆者等の 
責任こして之等に閣してはお互に最後迄連絡なし で實驗して結果を對決して調べを。

特に摩擦係數に對しては十分に吟味したが。此 の結果より使用に堪ず撤去されをるの淔流側 刷子にて $0.30 〜 0.31$ 以上のもの，良好ではない が辛じて使朋し得るこ稱され尼ものは0.29〜0.30 程度，優秀とさ就をるのは $0.28 \sim 0.29$ 以下で为 つ质. 又交流側の金露黑鉛刷于飞て注 0.28 以上 刀摩擦係数を有してんる刷子は多えご不合格已な り失格の䋈身をみている.

以上の貿驗の結果より今国別定した仕樣書內の 數值证現市販刷子の不良品を押える数值として不

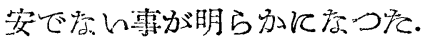

\section{26 年度の刷子試驗計畫について}

前逝迄の經過によつて設供機械用刷广として必 要存特性が明らかてされ，且つ忙愫書の值にも自 信艺得をので今年は而ら飞進步し党試驗を實施し 㸴究調查の基をつくり且つ業者の改良研究に泇力 する計畫で范る。

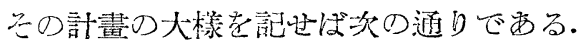

1 各業者より黑皮付プロックの提出を求めるて 之

2 各材質が仕用書の特性に合格ず尚や否を試驗 するると

3 規格に合格せるもののみ實地試驗を行ふこと 4 實地試驗飞到 Ncc 259, 又沬 Ncc SA-45 を
取付比較調查をずるこ己

5 特性試驗は十分慎重に行万關係上，闌鐵支研

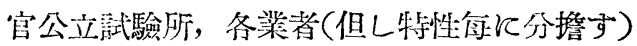
の三者にて行ん㑬結果の整理は總て推計學的 に整理すると己

6 ブロックの均一性を調查ずると

7 昭和 25 年度よりの進步改良の跡老調貸する 乙己

8 今包の試驗は購入資格試驗では卒く公認試驗 ¿して行々合格品のみにつんて登表するてと

以上の如き組織にて行うべく寝書中にて各關係

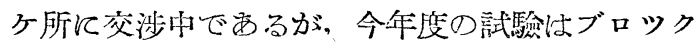
の均一监之和製品が艘來品飞比整して如何なる水

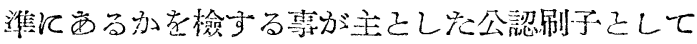
の試驗を行う像定で西る,(4月 28 日現在)

\section{7. 結 言}

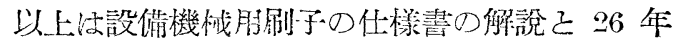

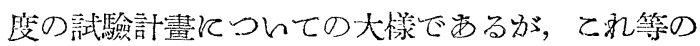
試驗絬果が全部明らかれされるの部て〜10月已思

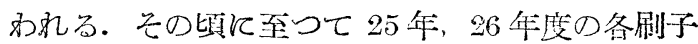
の特性，筫施試驗の絬果等を再び此の紙上で發表

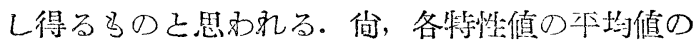
あり方或はブロックの不平均につんて等に關して

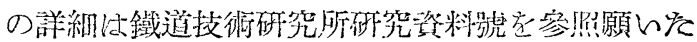
h.

は，

White, A. H. \& Germer, L. H. : J. Chen. Phys' 9 (1941) 492.

Wanen : J. Appl. Phys. 13 (1942) 364. 一不規則な

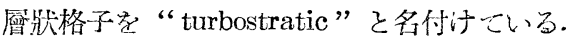

Rossman \& Smith : Ind. Eng. Chem. 35 (1943) 972 一粒子間の室隙の大きさを推算し, 又粒子の大きさ として, Carbolac 1 (ペイント用)は $5 \mathrm{~m} \mu, 10 \sim 15$ 層から成り, Shawinigan Acetylene Black は約 1,000 層, Rubber Channel Black は的 3,000 層 から成るとしている。

(向坊) 